\title{
PEMBERDAYAAN EKONOMI KERAKYATAN: PEMBUATAN MINYAK KELAPA MURNI (VIRGIN COCONUT OIL) DAN BLONDO DI DUSUN KRAJAN DESA BALET BARU KECAMATAN SUKOWONO KABUPATEN JEMBER
}

\author{
Anita Fitriya, Achmad Muhlis, \& Hamim Thohari \\ Institut Agama Islam Al-Qodiri Jember , Indonesia \\ anitafitriya16@gmail.com \\ achmadmuhliklis23@gmail.com \\ haamim67@gmail.com
}

\begin{abstract}
The aim of this operation is to improve the economy of the new community of ballet villages by using pure coconut fruit as a medium to become virgin coconut OIL and Blondo. The strategy employed is to use approach learning. And using the tool for interviewing, socializing and recording. (1) This determination results in virgin coconut oil being very healthy for the skin. (2) Blondo and pure coconut oil are ideal for continuous production, since they have a reasonably high economic value. The opportunity for profit is very positive. (3) The nationalist economic policy focussing on the production of virgin coconut oil (VCO / Virgin Coconut Oil) and blondo has a positive influence on job growth. (4) Can conserve local culture (local wisdom), that is to say, making traditional cooking oil which is an ancient practice so that it needs to be produced.
\end{abstract}

Keywords: Economy of the People; Pure coconut oil

\section{Pendahuluan}

Desa Balet Baru merupakan salah satu dari desa yang berada di kecamatan Sukowono. Des aini memiliki 2 (dua) dusun yaitu dusun 
sumbergayam dan dusun Krajan. Potensi desa adalah keseluruhan sumber daya yang dimiliki atau digunakan oleh desa baik sumber daya manusia, sumber daya alam dan kelembagaan maupun prasarana dan sarana untuk mendukung percepatan kesejahteraan masyarakat ${ }^{1}$. LETAK: Desa Baletbaru memiliki topografi dataran rendah dengan ketinggian tanah dari permukaan laut $\pm 87,30 \mathrm{Mdpl}$ dengan kemiringan tanah antara 3-3\%.

Data dasar keluarga adalah gambaran menyeluruh potensi dan perkembangan keluarga yang meliputi potensi sumber daya manusia, perkembangan kesehatan dan pendidikan, penguasaan asset ekonomi dan sosial keluarga, partisipasi anggota keluarga dalam proses pemerintahan, pembangunan dan kemasyarakatan serta berbagai permasalahan kesejahteraan keluarga dan perkembangan keamanan dan ketertiban di lingkungannya². Luas wilayah dan aspek penggunaan lahan sebagaimana table berikut: ${ }^{3}$

${ }^{1}$ Monika Ginting and Sorang Pakpahan, 'Sistem Informasi Potensi Kependudukan Desa Sukajulu Berbasis Web', MEANS (Media Informasi Analisa Dan Sistem), 2018, 147-51.

2 Edy Budiman, 'E-Government Data Profil Dan Monografi Kelurahan Dadi Mulya Kecamatan Samarinda Ulu Kota Samarinda', Jtriste, 3.1 (2016), 49-58.

${ }^{3}$ Desa Balet, 'Dokumentasi Dari Perangkat Desa Balet', 2020.

Vol. 2 No. 2, Oktober 2020 


\section{LUAS WILAYAH DAN ASPEK PENGGUNAAN LAHAN}

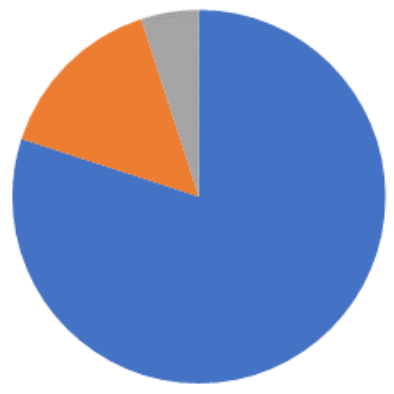

- 80\% (Persawahan)

15\% (Pemukiman)

$5 \%$ (Lain-lain)

Gambar 1. Luas Wilayah dan Aspek Penggunaan Lahan

Iklim Desa Baletbaru memiliki iklim tropis yang didominasi oleh musim panas serta musim hujan yang begitu cukup, rata-rata setiap tahunnya mencapai suhu $27^{\circ} \mathrm{C}-30^{\circ} \mathrm{C}$ serta curah hujan 210 $\mathrm{mm}$ /tahun, sehingga sangat cocok untuk bercocok tanam (terutama tanaman padi, palawija, jagung, tembakau) serta tumbuh subur pohon kelapa yang begitu banyak diarea persawahan.

Banyaknya manfaat yang terdapat pada pohon kelapa ternyata tidak sebanding dengan upaya masyarakat Desa Baletbaru dalam memanfaatkan dan mengolahnya. Hal ini justru menyisakan masalah berupa melimpahnya buah kelapa yang dari masa panen ke masa panen selanjutnya menjadi limbah atau sampah yang terbuang sehingga 
menimbulkan dampak negative. Berangkatnya dari masalah tersebut dengan bimbingan dosen pembimbing lapangan kuliah kerja mahasiswa Institut Agama Islam Al-Qodiri Jember bermaksud meningkatkan perekonomian masyarakat desa Baletbaru dengan pemberdayaan ekonomi kerakyatan dengan pembuatan minyak kelapa murni (virgin coconut OIL) dan blondo di dusun Krajan Desa Balet Baru Kecamatan Sukowono Kabupaten Jember.

\section{Metode}

Dalam melakukan pengabdian pada masyarakat ini, dilakukan beberapa program kegiatan yang dilaksanakan berdasarkan identifikasi masalah yang telah lalu. Pendekatan yang digunakan dalam kegiatan ini adalah learning by doing, dimana para peserta belajar mengolah buah kelapa dengan langsung praktek menggunakan media yang telah disiapkan ${ }^{4}$. Sehingga dengan pendekatan ini diharapkan dapat lebih efektif dan efesien terhadap luaran atau outcame kegiatan pengabdian kepada masyarakat di Desa Balet baru.

\footnotetext{
${ }^{4}$ Panji Nugraha, 'Penerapan Model Cooperative Learning Tipe Picture And Picture Untuk Meningkatkan Motivasi Dan Hasil Belajar Peserta Didik Pada Materi Keanekaragaman Kenampakan Alam Dalam Pembelajaran IPS' (FKIP UNPAS, 2016). 
Adapun Langkah-langkah yang digunakan dalam kegiatan pengabdian kepada masyarakat sebagaimana berikut:

1. Sosialisasi kebermanfaatan program buah kelapa menjadi minyak OIL

Program ini dilakukan dengan interview terhadap masyarakat tentang penentuan tema riset yang akan digunakan.

2. Pelatihan pengolahan Buah Kelapa menjadi OIL

Kegiatan ini merupakan kegiatan inti dari program kepada masyarakat Desa baru Balet. Kegiatan ini menggunakan Teknik praktikum mendatangkan pihak dengan bekerjasama dengan UMKM Desa setempat. Sasaran Sasaran dari adanya "Pemberdayaan program ekonomi kerakyatan: produksi minyak kelapa murni/Virgin Coconut Oil (VCO) dan Blondo" di dusun krajan desa Baletbaru Kec. Sukowono adalah masyarakat secara luas yang berada di desa Baletbaru umumnya, serta khususnya mayarakat di dusun krajan yang terdiri dari 14 RT atau 6 RW yaitu sekitar 897 kepala keluarga. Lebih spesifik lagi di RT 2 RW 13.Lebih khusus lagi adalah para ibuibu.

3. Sosialisasi Teknik kemasan dan Teknik survey harga standart pasaran

Kegiatan ini menggunakan Teknik ceramah dan diskusi tanya 
jawab serta survey terhadap para peserta yang terdiri dari para pemuda karang taruna dan ibu-ibu PKK desa balet baru.

Strategi yang dilakukan untuk mencapai kondisi yang diharapkan, misalnya5: PAR (Participatory Action Research); ABCD (Asset Based Community Development); CBR (Community-Based Research); Service learning; Communitydevelopment, atau metode pengabdian yang lainnya, pihak yang terlibat dan bentuk keterlibatan (patnership), tempat dan waktu kegiatan (lama proses pendampingan).

\section{Hasil dan Diskusi}

1. Pelaksanaan/proses pembuatan

"Pemberdayaan program ekonomi kerakyatan: produksi minyak kelapa murni/Virgin Coconut Oil (VCO) dan Blondo" di dusun krajan desa baletbaru kec.sukowono merupakan terobosan baru yang dibentuk oleh kelompok KKM Pos-Pemberdayaan Keluarga Berbasis Riset posko 4 Institut Agama Islam Al-Qodiri Jember. Sehingga harus banyak belajar dari yang lebih pengalaman.selain pencarian bahan baku yang cocok dengan produk dimaksud yaitu kelapa yang harus cukup tua bahkan

\footnotetext{
${ }^{5}$ Jutta Gutberlet, Urban Recycling Cooperatives: Building Resilient Communities (Routledge, 2016). 
kalau bissa yang sudah kering, karena dapat menghasilkan santan kelapa yang banyak serta cukup baik untuk produksi minyak kelapa murni dan blondo ini. Adapun proses pengolahannya adalah sebagai berikut:

Pertama-tama kelapa di kupas dari kulit sepatnya dan batok kelapanya. Kemudian air kelapanya dilainkan untuk kemudian bisa dijadikan bahan campuran pembuatan blondo yang memiliki rasa manis alami. Kelapa diparut untuk menghasilkan santan. Santan yang baik adalah proses perasan pertama, sementara santan diperas, kita membuat api ditungku untuk dijadikan proses mengolah santan. Kalau menginginkan agak manis maka ditambahkan air kelapa ssebagai perasan. Jika tidak, maka rasa original yang didapatkan. Santan terus di panaskan diatas wajan yang besar dengan pemanasan yang kontinyu dari awal. Setelah kurang lebih 3 sampai 5 jam dipanaskan dengan di aduk tanpa henti ,maka santan akan berubah manghasilkan minyak dan blondo/blittek. Tiap kelapa 6 biji yang kering akan menghasilkan 2,5 ons blondo serta $250 \mathrm{ml}$ minyak virgin Cococnut Oil. Dalam pembuatan 25 biji kelapa kering dapat menghasilkan 13 bungkus 
blondo dengan berat 200 gram serta minyak 15 botol dengan ukuran 100 mili liter.

2. Estimasi dana produksi dalam nilai ekonomi

Tabel 1. Estimasi dana produksi dalam nilai ekonomi

\begin{tabular}{|c|c|c|c|}
\hline NAMA ITEM & $\begin{array}{l}\text { JUMLAH } \\
\text { ITEM }\end{array}$ & $\begin{array}{l}\text { HARGA } \\
\text { SATUAN }\end{array}$ & JUMLAH \\
\hline Jumlah kelapa & 25 & Rp. 5000 & Rp. 125,000 \\
\hline Biaya pengupasan kelapa & 25 & Rp. 700 & Rp. 17,500 \\
\hline Biaya parutan kelapa & 25 & Rp. 900 & Rp. 22,500 \\
\hline $\begin{array}{l}\text { Biaya pengolahan santan } \\
\text { dan proses }\end{array}$ & & & Rp. 35,000 \\
\hline Biaya packaging & & & \\
\hline Minyak & 15 & Rp. 400 & Rp. 6,000 \\
\hline Blondo & 13 & Rp. 400 & Rp. 5,200 \\
\hline Kayu bakar & & & Rp. 10,000 \\
\hline Harga satuan plastik & 13 & Rp. 700 & Rp. 9,100 \\
\hline Botol kaca $100 \mathrm{ml}$ & 15 & Rp. 2000 & Rp. 30,000 \\
\hline Sticker & & & Rp. 8,000 \\
\hline \multicolumn{3}{|c|}{ Jumlah } & Rp. 268,300 \\
\hline
\end{tabular}

a. Harga satuan minyak ukuran 100 ml wadah botol kaca @@ RP.6000 rupiah

b. Harga satuan blondo ukuran 200 gram wadah plastik standing poach adalah 17.000.rupiah 
1. Jumlah hasil kemasan blondo yaitu 13 x Rp. 17.000,-= Rp. 221.000,-

2. Jumlah hasil minyak kemasan botol kaca adalah $15 x$ Rp. 6.500,-= Rp. 97.500,_

Dengan jumlah pembiayaan sebesar 268.300 rupiah dimana menghasilkan blondo sebanyak 13 bungkus dengan berat $200 \mathrm{~g}$ dan mimyak kelapa murni 15 botol dengan ukuran 100ml. Maka penghitungan laba ruginya adalah sebagai berikut:

Jumlah hasil penjualan minyak dan blondo adalah Rp. 221.000,$+97.500,-=318.500,-$

Jadi kalkulasi laba ruginya dalam perspektif ekonomi kerakyatan adalah jumlah hasil penjualan produksi dikurangi biaya produksi yaitu: Rp. 318.500- Rp. $268.300=$ Rp. 50.200,-

Jadi selain menciptakan lapangan pekerjaan disana ada nilai ekonomis yaitu ada laba dari proses produksi sebesar Rp. 50.200,-

3. Pengalaman serta tantangan menarik

Banyak hal yang kami ketahui program ini baik dari segi setting tempat, dan kondisi serta sulitnya proses pembuatan yang begitu sulit dan memakan waktu lama sangat mengnspirasi sehingga mengunggah semangat kami untuk melanjutkan program yang kami bentuk serta siap untuk mengembangkan program ekonomi kerakyatan posko 4 
yaitu pembuatan minyak kelapa murni dan blondo.bahkan selama proses pembuatan laporan sudah kami siap bawakan untuk diajukan izin ke pihak dinas kesehatan melalui dinas perizinan satu pintu kabupaten jember untuk mendapatkan label ijin produksi rumah tangga atau PIRT (Pangan industri rumah tangga).

\section{Pendukung}

Konsultasi dengan beberapa pemuda,pengurus takmir masjid, tokoh masyarakat setempat serta beberapa akdemisi serta dewan guru ngajiguna mengetahui hal-hal yang perlu kami lakukan dan kami persiapkan.

Beberapa pemuda serta tokoh masyarakat ikut andil dalam pelaksanaan taman baca. Mereka menyumbang beberapa buku untuk koleksitaman baca. Para guru ikut terbantu dengan adanya taman baca ini. Biasanya anak-anak ramai bermain saat hari libur, serta pemuda yang disore hari dan malam hari santai sekarang mereka lbih senang berada di taman baca meskipun hanyamelihat buku yang ada.

\section{Kendala Dan Solusi}

Alhamdulillah, dalam proses pembuatan berjalan dengan baik dari proses produksi. Namun kendala masa ekspaied blondo yang begitu cepat di luar pendingin adalah kesulitan dalam produksi, Namun ketika didalam kulkas/pendingin dapat bertahan cukup lama, bahkan 
sebulan lebih. Sementara minyak kelapa murni cukup bertahan lama, walaupun diluar pendingin, kendala lain adalah marketing yang masih mengandalkan sistem pesanan online, dimana ibu ibu yang kurang melek internet belum begitu memahaminya, akhirnya perlu adanya dukungan dari banyak pihak untuk memajukan industri rumahan ini, akhirnya minyak kelapa ini kami kemas dengan nama "Minyak Kelapa Khas Jember" "BISMIKA HOME INDUSTRI" untuk memiliki nilai paten, begitu juga blondo dengan nama "BLONDO KHAS JEMBER

\section{BISMIKA HOME INDUSTRI"}

6. Manfaat VCO Untuk kesehatan

a. Meningkatkan kadar kolesterol HDL.

Menurut Walter C. Willett, M.D., Harvard Medical School, manfaat minyak kelapa membantu meningkatkan kadar kolesterol HDL (kolesterol baik) yang membantu meningkatkan kesehatan jantung.

b. Menurunkan berat badan

Khasiat minyak kelapa juga bisa menurunkan berat badan. Minyak kelapa dingin yang tidak dimurnikan untuk rambut, kulit, dan memasak mengandung asam lemak rantai pendek dan menengah yang membantu dalam mengurangi berat badan berlebih.

Penelitian menunjukkan bahwa itu membantu mengurangi kegemukan perut pada wanita. Hal ini juga mudah dicerna 
dibandingkan dengan minyak nabati lainnya dan membantu dalam fungsi yang sehat dari sistem tiroid dan endokrin. Lebih lanjut, ini meningkatkan laju metabolisme tubuh dengan menghilangkan stres pada pankreas, dengan demikian, membakar lebih banyak energi dan membantu orang yang kegemukan dan kelebihan berat badan menurunkan berat badan ${ }^{6}$.

Oleh karena itu, orang yang tinggal di daerah pesisir tropis, yang menggunakan minyak kelapa setiap hari sebagai minyak goreng utama mereka, biasanya tidak gemuk atau kelebihan berat badan.

c. Meningkatkan kesehatan jantung

Asam laurat yang ada dalam minyak kelapa membantu aktif mencegah berbagai masalah jantung seperti kadar kolesterol tinggi dan tekanan darah tinggi ${ }^{7}$. Ini tidak mengarah pada peningkatan kadar kolesterol LDL, dan mengurangi insiden cedera dan kerusakan pada arteri, karena itu membantu mencegah aterosklerosis.

Sebuah penelitian menunjukkan bahwa asupan minyak kelapa ini dapat membantu dalam menjaga profil lipid yang sehat pada wanita pra-menopause ${ }^{8}$. Apakah itu baik atau buruk bagi hati?

6 I Putu Suiraoka, 'Penyakit Degeneratif', Yogyakarta: Nuha Medika, 2012, 45-51. ${ }^{7}$ Jamal Basmal, 'Ikan Gindara (Lepidocybium Flavobrunneum) Sebagai Sumber Asam Lemak Esensial', Journal of Squalene, 5.3 (2010), 109-17.

8 Wenny Rismasita Swetri, ‘Faktor Yang Berhubungan Dengan Keluhan 
d. Menyehatkan rambut

Apakah anda tahu alasan rambut panjang dan berkilau dari wanita pesisir? Ya, ini karena minyak kelapa. Wanita di daerah pesisir tropis di dunia menggunakan minyak kelapa untuk rambut hampir setiap hari. Minyak kelapa seperti mentega ini membantu menyehatkan rambut dan membuat rambut berkilau' ${ }^{9}$. Minyak kelapa juga sangat efektif dalam mengurangi kehilangan protein, yang jika tidak terkendali dapat menyebabkan berbagai kualitas tidak sehat di rambut Anda. Karena berat molekul rendah, ia mampu menembus batang rambut dan mencegah kerusakan rambut.

Minyak kelapa adalah alasan mengapa digunakan sebagai perawatan rambut, dan dalam pembuatan berbagai krim pelembab dan ketombe $^{10}$. Varietas terbaik untuk rambut sehat adalah minyak kelapa organik extra virgin. Aplikasikan saja secara topikal ke rambut anda atau gunakan masker rambut minyak kelapa.

Menopause Pada Wanita Menopause Di Kota Pontianak (Studi Pada Wanita Pra Lansia Di Wilayah Kerja UPTD/UPK Puskesmas Kecamatan Pontianak Timur)', 2018.

${ }_{9}$ Faisal M Sakri, Madu Dan Khasiatnya: Suplemen Sehat Tanpa Efek Samping (Diandra Kreatif, 2012).

${ }^{10}$ Gita Putri Listiyawati, Heru Nurcahyo, and Heni Purwantiningrum, 'Formulasi Dan Uji Sifat Fisik Shampo Kombinasi Merang Padi (Oryza Sativa L) Dan Ekstrak Bunga Kenanga (Cananga Odorata)' (Politeknik Harapan Bersama Tegal, 2021). 
e. Perawatan kulit

Tahukah Anda bahwa minyak kelapa sangat cocok untuk kulit. Menurut penelitian 2018 tentang efek minyak nabati pada kulit, minyak kelapa kaya akan antibakteri, antipenuaan, antioksidan, penyembuhan luka, dan sifat anti-inflamasi ${ }^{11}$.

Khasiat minyak kelapa juga membantu dalam mengobati berbagai masalah kulit yang meliputi ${ }^{12}$ :

1) Eksim \& Psoriasis : Pemakaian minyak kelapa murni secara topikal mengurangi tingkat keparahan kondisi ini.

2) Radiasi UV :Minyak kelapa melindungi kulit dari efek berbahaya dari sinar UV.

3) Dermatitis :Sebuah studi oleh Allison L. Goddard dan Peter A. Lio menunjukkan bahwa minyak kelapa efektif dalam mengurangi gejala dermatitis atopik dibandingkan dengan minyak mineral. Studi lain menemukan bahwa minyak kelapa murni dapat digunakan sebagai cara yang efektif untuk mengobati dermatitis atopic.

${ }^{11}$ F G Winarno, Tanaman Kelor (Moringa Oleifera): Nilai Gizi, Manfaat, Dan Potensi Usaha (Gramedia Pustaka Utama, 2018).

${ }^{12}$ Haerani Haerani, 'Pemanfaatan Limbah Virgin Coconut Oil (Blondo)', Media Kesehatan Masyarakat Indonesia Universitas Hasanuddin, 6.4 (2010), 244-48. 
4) Luka kulit :Virgin coconut oil membantu mempercepat penyembuhan luka.

5) Xerosis atau kulit kering :Minyak kelapa murni organik, nontransgenik murni adalah minyak pijat yang sangat baik yang bertindak sebagai pelembap yang efektif untuk semua jenis kulit, termasuk kulit kering untuk menghilangkan bau alami biasa dicampur minyak telon.

6) Aktivitas Antimikroba :Monolaurin adalah komponen aktif dari minyak kelapa yang ditemukan bersifat antibakteri, antivirus, dan antijamur. Ini melindungi terhadap efek berbahaya dari bakteri seperti Staphylococcus aureus yang menyebabkan jerawat dan infeksi kulit lainnya.

7) Luka bakar :Penggunaan minyak kelapa membantu mengobati luka bakar secara efektif Tidak seperti minyak mineral, tidak ada kemungkinan memiliki efek samping pada kulit dari aplikasi minyak ini. Oleh karena itu, telah digunakan dengan aman selama ribuan tahun untuk mencegah kekeringan dan pengelupasan kulit.

f. Membantu mengobati penyakit Alzheimer

Sebuah penelitian baru-baru ini menunjukkan bahwa manfaat minyak kelapa meningkatkan kemampuan kognitif pada pasien Alzheimer. MCT (Medium Chain Triglycerides) yang ditemukan dalam 
minyak kelapa adalah sumber keton sangat baik yang dapat peningkatan memori. Tetapi data klinis dan ilmiah lebih lanjut diperlukan untuk memastikan apakah minyak kelapa benar-benar meningkatkan fungsi otak dalam bentuk apa pun.

g. Mencegah infeksi ragi - Candida

Candida, juga dikenal sebagai kandidiasis sistemik, adalah penyakit tragis yang disebabkan oleh pertumbuhan ragi yang berlebihan dan tidak terkendali yang disebut Candida albicans di perut. Sebuah studi tentang minyak kelapa menunjukkan bahwa itu memberikan bantuan dari peradangan yang disebabkan oleh Candida, baik secara eksternal maupun internal. Kapasitas penahan kelembapannya yang tinggi membuat kulit tidak retak atau terkelupas. Asam kaprat, asam kaprilat, asam kaproat, asam miristat, dan asam laurat yang ditemukan dalam minyak kelapa membantu menghilangkan Candida albicans.

Lebih lanjut, tidak seperti perawatan farmasi lain untuk candida, efek minyak kelapa bersifat bertahap dan tidak drastis atau tiba-tiba, yang memberikan pasien sejumlah waktu yang tepat untuk membiasakan diri dengan gejala penarikan atau reaksi Herxheimer (nama yang diberikan untuk gejala yang menyertai tubuh). Penolakan racun yang dihasilkan selama eliminasi jamur ini). Tetapi dalam 
perawatan kondisi ini, orang-orang harus secara sistematis dan bertahap meningkatkan dosis minyak kelapa mereka, dan seharusnya tidak memulai dengan jumlah yang besar.

h. Mempercepat penyembuhan

Ketika diaplikasikan pada area yang terinfeksi, minyak kelapa membentuk lapisan kimia yang melindungi bagian tubuh yang terinfeksi dari debu luar, udara, jamur, bakteri, dan virus. Ini sangat efektif pada memar karena mempercepat proses penyembuhan jaringan yang rusak.

i. Meningkatkan imunitas

Minyak kelapa memperkuat sistem kekebalan tubuh karena mengandung lipid antimikroba, asam laurat, asam kaprat, dan asam kaprilat, yang memiliki sifat antijamur, antibakteri, dan antivirus. Tubuh manusia mengubah asam laurat menjadi monolaurin, yang mana penelitian telah mendukung sebagai cara yang efektif untuk menangani virus dan bakteri yang menyebabkan penyakit seperti herpes, influenza, cytomegalovirus, dan bahkan HIV. Minyak kelapa membantu dalam memerangi bakteri berbahaya seperti Listeria monocytogenes dan Helicobacter pylori, dan protozoa berbahaya seperti Giardia lamblia.

j. Mencegah IBS dan masalah pencernaan lainnya 
Manfaat minyak kelapa cair membantu meningkatkan sistem pencernaan, dan dengan demikian, mencegah berbagai masalah perut termasuk sindrom iritasi usus (IBS). Lemak jenuh yang ada di dalamnya memiliki sifat antimikroba dan membantu dalam menangani berbagai bakteri, jamur, dan parasit yang dapat menyebabkan gangguan pencernaan. Minyak kelapa efektif dalam menghilangkan konstipasi. Ini juga membantu dalam penyerapan nutrisi lain seperti vitamin, mineral, dan asam amino. ${ }^{13}$

\section{Kesimpulan}

Dari hasil riset yang dilakukan terhadap program ekonomi kerakyatan focus pengolahan minyak kelapa murni (VCO/Virgin Coconut Oil) dan Blondo oleh KKM Posko 4 IAI Al-Qodiri di dusun Krajan desa baletbaru kecamatan sukowono kabupaten jember bias ditarik kesimpulan bahwa: (1) Minyak kelapa murni sangat baik untuk kesehatan; (2) Minyak kelapa murni dan blondo baik untuk terus di produksi karena memiliki nilai ekonomi yang cukup tinggi.nilai laba yang cukup menjanjikan; (3) Program ekonomi kerakyatan focus pengolahan minyak kelapa murni(VCO/Virgin Coconut Oil) dan Blondo iniberdampak positip bagi penciptaan lapangan kerja; (4) Bisa menjaga tubuh.

${ }^{13}$ https://doktersehat.com/manfaat-minyak-kelapa-bagi-perawatan- 
budaya local (local wisdom) yaitu membuat minyak goreng tradisional yang merupakan tradisi jaman dulu sehingga perlu dibudayakan.

\section{Keberlanjutan program}

Demi berlanjutnya program ini, kami membentuk pengurus dengan harapan bisa terkoordinasi dengan baik.serta kami mengharapkan dukungan banyak pihak untuk pemberdayaan program ini kedepan, mengingat program ini cukup menjanjikan untuk dikembangkan.

\section{Rekomendasi}

Pihak peneliti lain dan pendamping seperangkat desa untuk tetap mengawal keberlanjutan program ini. Karena melihat potensi tempat yang cocok untuk di jadikan program ekonomi kerakyatan. Menurut kami, tempat tersebut sangat strategis untuk dijadikan pusat ekonomi kerakyatan yang berjenjang untuk jangka panjang panjangnya.

\section{Daftar Pustaka}

Balet, Desa, 'Dokumentasi Dari Perangkat Desa Balet', 2020

Basmal, Jamal, 'Ikan Gindara (Lepidocybium Flavobrunneum) Sebagai Sumber Asam Lemak Esensial', Journal of Squalene, 5.3 (2010), 109_ 17

Budiman, Edy, 'E-Government Data Profil Dan Monografi Kelurahan Dadi Mulya Kecamatan Samarinda Ulu Kota Samarinda', Jtriste, 


\section{$3.1(2016), 49-58$}

Ginting, Monika, and Sorang Pakpahan, 'Sistem Informasi Potensi Kependudukan Desa Sukajulu Berbasis Web', MEANS (Media Informasi Analisa Dan Sistem), 2018, 147-51

Gutberlet, Jutta, Urban Recycling Cooperatives: Building Resilient Communities (Routledge, 2016)

Haerani, Haerani, 'Pemanfaatan Limbah Virgin Coconut Oil (Blondo)', Media Kesehatan Masyarakat Indonesia Universitas Hasanuddin, 6.4 (2010), 244-48

Listiyawati, Gita Putri, Heru Nurcahyo, and Heni Purwantiningrum, 'Formulasi Dan Uji Sifat Fisik Shampo Kombinasi Merang Padi (Oryza Sativa L) Dan Ekstrak Bunga Kenanga (Cananga Odorata)' (Politeknik Harapan Bersama Tegal, 2021)

Nugraha, Panji, 'Penerapan Model Cooperative Learning Tipe Picture And Picture Untuk Meningkatkan Motivasi Dan Hasil Belajar Peserta Didik Pada Materi Keanekaragaman Kenampakan Alam Dalam Pembelajaran IPS' (FKIP UNPAS, 2016)

Sakri, Faisal M, Madu Dan Khasiatnya: Suplemen Sehat Tanpa Efek Samping (Diandra Kreatif, 2012)

Suiraoka, I Putu, 'Penyakit Degeneratif', Yogyakarta: Nuha Medika, 2012, $45-51$

Swetri, Wenny Rismasita, 'Faktor Yang Berhubungan Dengan Keluhan Menopause Pada Wanita Menopause Di Kota Pontianak (Studi Pada Wanita Pra Lansia Di Wilayah Kerja UPTD/UPK Puskesmas Kecamatan Pontianak Timur)', 2018

Winarno, F G, Tanaman Kelor (Moringa Oleifera): Nilai Gizi, Manfaat, Dan Potensi Usaha (Gramedia Pustaka Utama, 2018) 